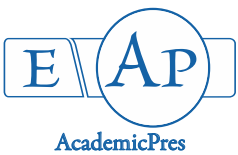

Borah PJ et al. (2021)

Notulae Scientia Biologicae

Volume 13, Issue 3, Article number 11027

DOI: $10.15835 / \mathrm{nsb} 13311027$

Review Article

\title{
A review on ethnopharmacological utility, traditional knowledge and phytochemistry of Aristolochia species in Assam, India
}

\author{
Punam J. BORAH ${ }^{1}$, Dipankar BORAH ${ }^{2 *}$, Udipta DAS ${ }^{3}$, \\ Tridip J. DAS ${ }^{4}$, Ruma SARMA ${ }^{1}$ \\ ${ }^{1}$ Cotton University, Department of Botany, Guwahati 781001, Assam, India; punamborah1997@gmail.com; \\ sarmaruma8@gmail.com \\ ${ }^{2}$ Goalpara College, Department of Botany, Goalpara 783101, Assam, India; \\ dipankar.borah@goalparacollege.ac.in (" ${ }^{*}$ corresponding author) \\ ${ }^{3}$ Tripura University, Department of Botany, Agartala 799022, Tripura, India; udiptadas93@gmail.com \\ ${ }^{4}$ NIT Arunachal Pradesh, Department of Biotechnology, Yupia 791112, Arunachal Pradesh, India; tridipjd31@gmail.com
}

\begin{abstract}
Aristolochia L. (Aristolochiaceae) is widely used throughout South-East Asia for the treatment of several diseases. Different species of this genus are known by similar local names in Assam. This review aims to provide up-to-date information on Aristolochia species distributed in Assam, including its traditional uses, phytochemical and pharmacological properties, in exploring future therapeutic and scientific potentials. The information on ethnobotany, phytochemistry and pharmacological aspects were collected by performing literature searches. Assam hosts a total of six species of Aristolochia. The taxonomy and distribution are presented. Traditionally the tubers are used by the local people to treat stomach pain, malaria, dysentery, high blood pressure, body pain, urinary tract infections, headache, impotency etc. It has considerable pharmacological properties including antimicrobial, antioxidant, anti-inflammatory, anti-cancer, anti-diabetic, anti-fertility, anti-venom, anti-diarrhoeal, anti-pruritic, anti-feedant and toxicological activities. Approximately a total of 200 compounds have been isolated from these species. So far, pharmacological investigations are only done on three Aristolochia species, whereas the other three are simultaneously used for the same purposes. Most of the medicinal properties attributed to these Aristolochia, have not yet been investigated and proven under a scientific study. This highlights the importance of Aristolochia as a valuable candidate for future studies.
\end{abstract}

Keywords: Aristolochia; bioactive compounds; distribution; flora of Assam; pharmacology; taxonomy; traditional knowledge

\section{Introduction}

Medicinal plants serve humans as a great source of therapeutics and pharmaceutical manufacturing. The practices of using medicinal plants in the treatment of common diseases are part of the traditional knowledge among the different communities throughout the world. The dependencies of the traditional communities on the naturally occurring herbs are due to better cultural acceptability, compatibility and adaptability of the

Received: 13 Jul 2021. Received in revised form: 04 Aug 2021. Accepted: 09 Aug 2021. Published online: 18 Aug 2021. From Volume 13, Issue 1, 2021, Notulae Scientia Biologicae journal uses article numbers in place of the traditional method of continuous pagination through the volume. The journal will continue to appear quarterly, as before, with four annual numbers. 
plants with the human body and lesser side effects (Gupta et al., 2010; Oladeji, 2016). Research carried out during the past few years have resulted in the isolation of more than a thousand bioactive compounds from medicinal plants having disease-preventing properties as antioxidants, detoxifying agents, immunitypotentiating agents and neuropharmacological agents (Saxena et al., 2013).

The increasing demands of herbal medicine in the 21 st century in both developed and developing countries indicate the public interest in traditional, complementary and alternative medicines. There is a belief that herbal medicines provide long-lasting healing, minimal adverse effects, lesser cost, well-practiced knowledge and promote healthier living in contrast to the adverse effects of allopathic drugs (Gupta et al., 2010). In rapidly developing countries such as India and China, the role of plant-derived medicine in the health care system is about $80 \%$ (Khan, 2016). The active phytoconstituents may be a mixture of secondary metabolites like alkaloids, saponins, tannins, glycosides, phenols and flavonoids etc. The extraction, isolation, detection and identification of such phytochemicals are necessary for establishing the quality control, mechanism of their action on the body, safety and efficacy (Saxena, 2013; Ogunmefu, 2018).

The genus Aristolochia L. (Aristolochiaceae) is widely distributed in tropical to temperate regions throughout the world (Hwang et al., 2003). It is the largest genus in the family accounting for about 534 accepted species (POWO, 2019), of which India is represented by 20 species (Borah et al., 2019; revised). They are mostly perennial climbers, with ovate cordate leaves and fusiform rhizomes. It can be differentiated from its other congeners (Saruma Oliv., Thottea Rottb. and Asarum L.) by a combination of several characters such as woody or herbaceous habit, axillary flowers arranged in fascicles or solitary, uniseriate perianth, connate carpels and dry capsules.

Among the 20 species of Aristolochia distributed in the country, six of them are presently reported growing wild from the state of Assam (Borah et al., 2019). Aristolochia indica L. is found in Lower Assam, A. cathcartii Hook.f. is distributed towards the both the banks of the River Brahmaputra in Upper Assam, whereas A. saccata Wall. is towards its South bank (doubtful). A. platanifolia (Klotzsch) Duch., A. assamica D. Borah \& T.V. Do towards the foothills of Arunachal Pradesh in Upper Assam, on either side of the Brahmaputra basin and $A$. acuminata Lam. (syn: A. tagala Cham.) is found throughout the region and is the most widespread species, among its congeners (Figure 1). A. cathcartii, A. platanifolia and $A$. saccata falls under the subgenus Siphisia and can be differentiated from all other species by their strongly curved perianth, U- or horseshoe shaped tube and a 3-lobed gynostemium. A. cathcartii and A. saccata are very close allies and are often confused, $A$. cathcartii is recognized by rectangular limb, inner surface of limb lobes covered with bristlelike papillae and purple dotted throat vs. irregularly circular limb, papillae and dots absent in $A$. saccata. Whereas, A. platanifolia can be distinguished from both of them, by its dissected leaves and a bell-shaped limb. The remaining three falls under the subgen. Aristolochia series Podanthemum and subgen. Aristolochia series Aristolochia. A assamica can be recognized by the absence of stipe absent between the ovary and the utricle and terete branches (series Aristolochia) vs. stipe present between the ovary and the utricle and branches angular or ribbed (series Podanthemum with the remaining two species). A. acuminata is distinguished by orbicular to ovate lamina with a long petiole up to $5 \mathrm{~cm}$ whereas, $A$. indica by obtuse-oblong to oblonglanceolate lamina with a short petiole up to $2 \mathrm{~cm}$ (Do et al., 2015; Borah et al., 2019).

However, no comprehensive review of the genus has been reported from this particular region. The present review is aimed to focus on providing information about traditionally used natural medicine, phytochemistry and pharmacology of Aristolochia species from Assam, India. We tried summarizing the best available evidence of traditional uses, phytoconstituents and pharmacological activities regarding Aristolochia spp. along with structural features of some important phytoconstituents. Multiple databases and platforms Google Scholar, Scopus, PubMed, Web of Science, ResearchGate and Academia were searched for relevant studies which included multiple keywords to elicit the data on Aristolochia. Chemical structures were drawn using Chem Draw Ultra 8.0 software by following the PubChem database (Figure 2). 

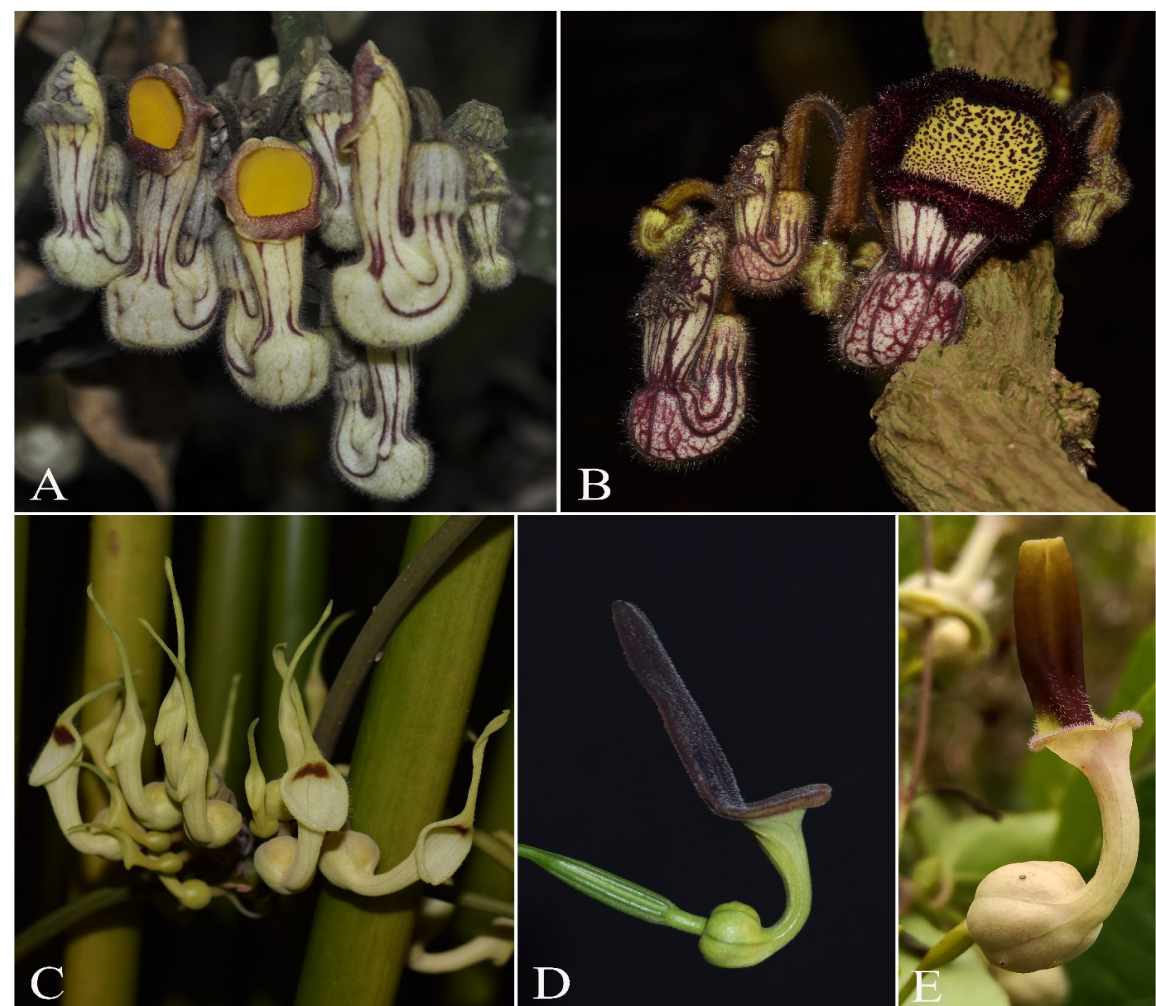

Figure 1. Aristolochia species distributed in Assam: A. A. platanifolia, B. A. cathcartii, C. A. assamica, D. A. acuminata, E. A. indica

(A by Khyanjeet Gogoi, B-D by Dipankar Borah \& E by Goutam Panda)

\section{Traditional uses of Aristolochia species}

Aristolochia spp. has been used in traditional medicine by different communities around its occurrence for a long time. The tubers of Aristolochia are used against a multitude of ailments in Assam. Correlating the ethnomedicinal reports with modern pharmacological and phytochemistry studies, shows consistency with the latest findings. A. acuminata is used to treat diarrhoea and dysentery by several tribes residing in Assam (Rao, 2019). A. saccata is used to treat stomach ache, constipation, dysentery, fever, body pain, jaundice, sprains and fracture by the Karbi, Tiwa, Pnar and Bodo-Kachari people residing in Karbi-Anglong districts of Assam (Basumatary et al., 2014; Teron, 2019). The population in Majuli Island and around Gibbon Wildlife Sanctuary uses its roots to treat tonsillitis, cough, piles, malaria fever and diarrhoea (Sarmah and Saikia, 2014; 2016). The roots of $A$. indica are used to heal wounds and to enhance fertility in males by the traditional healers of Dhemaji district of Assam (Taid et al., 2014). It has also been reported to be used by the people of DibruSaikhowa Biosphere Reserve for the treatment of certain asthmatic problems and skin diseases such as leucoderma (Nath et al., 2008; Purkayastha et al., 2007). The Deori, Muttak and Nepalesecommunity residing in the Dibrugarh district of Assam reported using the decoction of the leaves of $A$. indica to treat dysentery, diarrhoea and melena (Borah et al., 2006). A. cathcartiii is used against stomach aches, urinogenital disorders and as an insect repellent by the people in and around Manas Biosphere Reserve (Paul et al., $2011 \mathrm{a}, \mathrm{b}$ ). Similarly, the roots of $A$. assamica and $A$. cathcartii are used to treat stomach pain, malaria, dysentery, high blood pressure, body pain, urinary tract infections, headache and cough by the fringe people of Behali reserve forest in Biswanath district (Borah et al., 2020). However, several other ethnomedicinal reports have been published for the studied species of Aristolochia outside Assam are shown in Table 1. 
Table 1. Summary of traditional uses of the studied Aristolochia species outside Assam

\begin{tabular}{|c|c|c|c|c|c|}
\hline Species & Local names & Parts used & Traditional uses & Regions & References \\
\hline A. indica & $\begin{array}{c}\text { Aadagam, Aaduthinnapalai, Adgam, } \\
\text { Aduthinnapalai, } \\
\text { Beelieshwariballi,Bhedijanete, } \\
\text { Bhedijanetet (Santali), } \\
\text { Cheriyaarayan, Chong-khengsum, } \\
\text { Chotoishe, Eeshwariballi, } \\
\text { Eeshwariballi, Eeswaramool, } \\
\text { Eshwaramooli, Eshwarigida, } \\
\text { Eswaramooleekai, Garudakodi, } \\
\text { Ghorth, Gorisal, Ichegach, } \\
\text { Ichharmuli, Isharmul, Ishermul, } \\
\text { Ishwaraberu, Ishwarmon, } \\
\text { Ishwarmul, Isramuli, Israul, Iswar, } \\
\text { Iswaramuli, Iswari, Iswarmul, } \\
\text { Iswarmula, Kalesar, Karakalam, } \\
\text { Karudakodi, Kirmar, Nagasaram, } \\
\text { Nagbel, Nalla Eshwari, Nalla Eswari, } \\
\text { Nalleshwari, Nalleswari, } \\
\text { Perumanthikodi, Perumarindu, } \\
\text { Saapsun, Safed ishri, Sivan mooligai, } \\
\text { Sunanda, Tang gwaysobawai, } \\
\text { Thalaisuruli, Thazhaisurulikodi, } \\
\text { Thella usiri }\end{array}$ & $\begin{array}{c}\text { Bark, Fruit, Leaf, } \\
\text { Root, Root-bark, } \\
\text { Stem, Tuber, } \\
\text { Twig, Whole } \\
\text { plant }\end{array}$ & $\begin{array}{l}\text { Abortifacient, Analgesic, Anodyne, } \\
\text { Anti-inflammatory, Antibiotic, } \\
\text { Antidote against poison, } \\
\text { Antihelmintic, Aphrodisiac, } \\
\text { Asthma, Blood purifier, Bowel } \\
\text { complaints, Burns, Cardio tonic, } \\
\text { Cattle bloat, Cattle diarrhoea, } \\
\text { Cattle fever, Cholera, Cold \& } \\
\text { cough, Colic, Dandruff, Diarrhoea, } \\
\text { Diuretic, Dyspepsia, Eczema, } \\
\text { Emmenagogue, Ephemeral, Fever, } \\
\text { Folk belief, Gastric diseases, } \\
\text { Gonorrhea, Hemorrhagic } \\
\text { septicemia, Headache, Herpes, } \\
\text { High blood pressure, Horn } \\
\text { ablation, Injury, Insect bite, } \\
\text { Intermittent fever, Jaundice, } \\
\text { Leishmaniasis, Leprosy, } \\
\text { Leucoderma, Leucorrhoea, Liver } \\
\text { diseases, Madness, Malarial fever, } \\
\text { Mastitis, Menstrual problems, } \\
\text { Mosquito bite, Nervous disorders, } \\
\text { Neuro-Tonic, Oral infection, } \\
\text { Paralytic disease of cattle, Piles, } \\
\text { Pneumonia, Poison bite, Pruritus, } \\
\text { Rash, Rheumatic Arthritis, } \\
\text { Rheumatic fever, Rheumatic pain, } \\
\text { Scabies, Scorpion bite, Septic due to } \\
\text { skin allergies, Sexual problems, Skin } \\
\text { diseases, Snake bite, STD, Stomach } \\
\text { ache, Stomach disorders, Snake } \\
\text { repellant, Tooth-ache, Tumor, } \\
\text { Ulcers, Unconsciousness, Uterine } \\
\text { flow, Worm infection, Treating } \\
\text { wounds. }\end{array}$ & $\begin{array}{c}\text { India (Andhra Pradesh, } \\
\text { Gundlabrahmeswaram Wildlife } \\
\text { Sanctuary, Eastern Ghats, } \\
\text { Himachal Pradesh, Jharkhand, } \\
\text { Karnataka, Kerala, } \\
\text { Parambikulam Wildlife } \\
\text { Sanctuary, Madhya Pradesh, } \\
\text { Naoradehi Wildlife sanctuary, } \\
\text { Maharashtra, Orissa, Rajasthan, } \\
\text { U.T of Puducherry, Tamil } \\
\text { Nadu, Kodiakarai Reserve } \\
\text { Forest, Uttar Pradesh, West } \\
\text { Bengal) and Bangladesh }\end{array}$ & 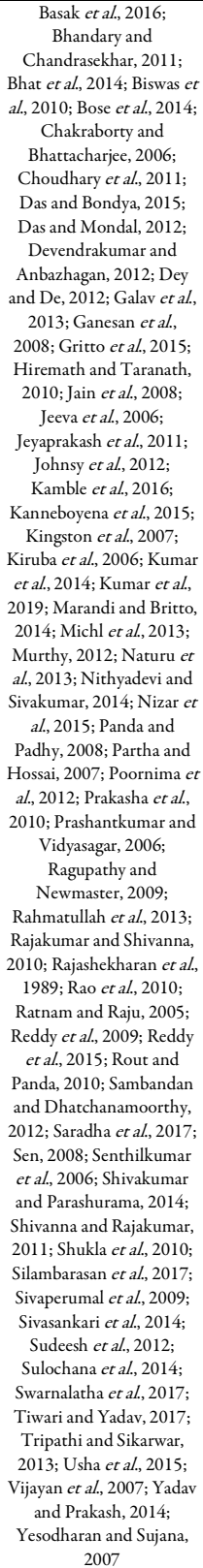 \\
\hline A. acuminata & $\begin{array}{c}\text { Eswaramulli, Eachamulla, } \\
\text { Garudakkody, } \\
\text { Isswarmuli, } \\
\text { Jarboporol, } \\
\text { Khurthlong, } \\
\text { Mala aryan, } \\
\text { Malaiarasam, } \\
\text { Nsoihenchi, } \\
\text { Peru eswaramooligai, } \\
\text { Valiyaarayan }\end{array}$ & $\begin{array}{l}\text { Fruits, Leaves, } \\
\text { Roots, Stem }\end{array}$ & $\begin{array}{c}\text { Abdominal pain, } \\
\text { Abortifacient, Analeptic, } \\
\text { Antipyretic, Anti-inflammatory, } \\
\text { Bone Fracture, Bilious disorders, } \\
\text { Carminative, Diarrhoea, Dysentry, } \\
\text { Emmenagogue, Health tonic, Loss } \\
\text { of appetite, Malaria, Muscle } \\
\text { relaxant, } \\
\text { Rheumatism, Regulate menstrual } \\
\text { disorders, Snake Bite, } \\
\text { Stomach ache, Swollen limbs, } \\
\text { Stimulate uterine flow, Snake and } \\
\text { Scorpion poison, } \\
\text { Tumour, Venereal disease }\end{array}$ & $\begin{array}{c}\text { India (Arunachal Pradesh, } \\
\text { Agasthiayamalai Biosphere } \\
\text { Reserve, South India, Kerala, } \\
\text { Meghalaya, Nagaland, Tamil } \\
\text { Nadu, } \\
\text { Trivandrum, } \\
\text { Tripura, } \\
\text { The Western Ghats, } \\
\text { Tirunelveli hills), } \\
\text { Bangladesh, } \\
\text { Indonesia, Philippines, } \\
\text { Thailand }\end{array}$ & $\begin{array}{c}\text { Biswas et al., 2010; } \\
\text { Britto and Mahesh, 2007; } \\
\text { Dey et al., 2012; } \\
\text { Devi Prasad et al., 2013; } \\
\text { Ignacimuthu and Ayyanar, } \\
\text { 2005; Kayang, 2007; Bose } \\
\text { et al., 2014; } \\
\text { Rajashekharan et al., 1989; } \\
\text { Rahman et al., 2007; } \\
\text { Reang et al., 2016; } \\
\text { Sulochana et al., 2014; } \\
\text { Silambarasan et al., 2017; } \\
\text { Santhosh Kumar et al., } \\
\text { 2019; Tripatara et al., } \\
\text { 2012 }\end{array}$ \\
\hline
\end{tabular}


Borah PJ et al. (2021). Not Sci Biol 13(3):11027

\begin{tabular}{|c|c|c|c|c|c|}
\hline A. saccata & Batelong, Krahlahit, Rikang & $\begin{array}{l}\text { Leaves, Roots, } \\
\text { Stem, Tubers }\end{array}$ & $\begin{array}{c}\text { Body pain, Diarrhoea, Dysentery, } \\
\text { Haemorrhage, Jaundice, } \\
\text { Tonsil }\end{array}$ & $\begin{array}{c}\text { Arunachal Pradesh, Meghalaya, } \\
\text { Nagaland }\end{array}$ & $\begin{array}{c}\text { Basumatary et al., 2014; } \\
\text { Kayang, 2007; } \\
\text { Teron and Borthakur, } \\
\text { 2013; } \\
\text { Rao, } 2019\end{array}$ \\
\hline A. cathcartii & & $\begin{array}{l}\text { Leaves, Rhizome, } \\
\text { Roots, Stem }\end{array}$ & $\begin{array}{l}\text { Food poisoning, Insect repellent, } \\
\text { Liver disorders, Promotes flow of } \\
\text { urine, Stomach ailments }\end{array}$ & Meghalaya & $\begin{array}{c}\text { Kayang, 2007; Syiem et al, } \\
2006\end{array}$ \\
\hline
\end{tabular}

\section{Reported phyto-compounds from Aristolochia species}

The phytochemical analysis is must to justify the scientific accuracy in the usage of herbal medicine and unearth the basis of treating diseases efficiently. During the last couple of decades, extensive studies were done on the phytochemical constituents found in various plant species and the genus Aristolochia was no exception. The phytoconstituents of the genus were extensively studied and many scholars have reported numerous compounds of significant importance from the plants of this genus. Aristolochic acids and it's derivatives, aristolactams, aporphines, protoberberines, isoquinolines, benzylisoquinolines, amides, flavonoids, lignans, diphenyl ethers, coumarins, tetralones, terpenoids, benzenoids, steroids were the secondary metabolites that have been characterized from the Aristolochia species (Kuo et al., 2012). In this section of the review, the constituents found in 3 out of 6 species of Aristolochia found in Assam are compiled and comprehensively presented in tabulated form (Table 2). Reliable data regarding the phytochemical constituents present in three species viz. A. saccata, A. platanifolia and $A$. assamica were not found which indicates that scientific analysis of phytochemical constituents present in those species is yet to be isolated and studied.

Table 2. Phyto-constituents of Aristolochia species distributed in Assam

\begin{tabular}{|c|c|c|c|}
\hline Species & Phyto-constituents reported & Plant part & References \\
\hline \multirow{8}{*}{ A. acuminata } & Kaempferol & Root & Battu et al., 2011 \\
\hline & Aristolochic acid I & Leaves & Ioset et al., 2002 \\
\hline & Aristolochic acid A, Aristolochic acid D & & Mix et al., 1982 \\
\hline & Aristolochic acid A, Tuberosinone & & Chen et al., 1987 \\
\hline & $\begin{array}{c}\text { Aristolactam C IIIa, Dehydrooxoperezinone, Pyriferine A, Isocorydine, Lagesianine A, } \\
\text { Kaempferol, 3,5-Di- O-caffeoylquinic acid, Aristolactam IIIa; N-b-D-Glucopyranosyl } \\
\text { isomer, Aristolactam IIIa; O-B-D-Glucopyranoside isomer, Aristolochic acid I, 4-O-beta-D- } \\
\text { glucosyl-4-coumaric acid, Leptantine, Madolin W/K/A/R, Perillyl acetate, Beta sistosterol, } \\
\Delta \text {-13,14-2-Oxokolavenic acid, Madolin L/M/S, 3-Oxoishwarane, Aristolactone, } \\
\text { Stigmasterol, Stigmastane-3,6-diol; (3b, 5a, 6a, 24R)-form, Diketone }\end{array}$ & Roots & Hadem et al., 2019 \\
\hline & Aristolochic acid I, Aristolochic acid II & Root & Tripatara et al,, 2012 \\
\hline & Anthocynidin 3-glycosides and 6-hydroxylated flavonols, Chalcone glycosides & Root & Hadem et al., 2016 \\
\hline & $\begin{array}{l}\text { Aristolactam BII, Aristolactam II, Sauristolactam, Aristolactam I, Aristolactam AII, 7- } \\
\text { methoxyaristolactam IV, 3-hydroxy-4-methoxy-10-nitrophenanthrene-1-carboxylic acid } \\
\text { methyl ester, Ariskanin A, Ariskanin D, Ariskanin E, Aristolochic acid C, Ariskanin C, } \\
\text { Ariskanin B, Aristolactam-N- } \beta \text {-Dglucoside, Cepharanone A N- } \beta \text {-D-glucoside }\end{array}$ & Whole plant & Liu et al., 2020 \\
\hline \multirow{5}{*}{ A. indica } & $\begin{array}{c}\text {-Caryophyllene, } \alpha \text {-Humulene, Ishwarone, Caryophyllene oxide I, Ishwarol, Linalool, } \alpha \text { - } \\
\text { Terpinolene, Ishwarane, Aristolochene, Cis-3-Hexenol, Germacrene D, Octen-3-ol, } 3 \text { - } \\
\text { Hexenyl acetate, Camphor, Nonanol, Humulene oxide, Nerolidol, } \beta \text {-Farnesene, } \beta \text { - } \\
\text { Bisabolene, Pinocarveol, } \delta \text {-Cadinol, } \beta \text {-Elemene, } \alpha \text {-Terpineol, } \beta \text {-Farnesol, Octanol, } \\
\text { Caryophyllene oxide II, } \alpha \text {-Bisabolol, Germacrene A, Ledol, 2- Octanol, Hexyl acetate, } \\
\text { Thymol, Indole, } \beta \text {-Phellandrene, Tetradecanol, } 5 \beta H, 7 \beta, 10 \alpha \text {-selina4(14),11-diene, } \beta \text {-Pinene, } \\
\text { Borneol, Terpinene- } 4 \text {-ol, } \beta \text {-Selinene, Hexanol, }(12 S)-7,12 \text {-Secoishwaran-12-ol, Camphene, } \\
\text { Tricyclene }\end{array}$ & Aerial part & Jirovetz et al., 2000 \\
\hline & 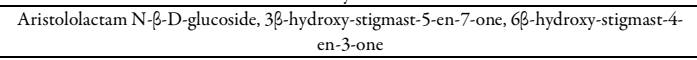 & Root & Achari et al., 1981 \\
\hline & $\begin{array}{l}\text { Aristolochic acid I, Aristolochic acid-D, Methyl Aristolochate, Aristolactam-A II, } \\
\text { Aristolactam I, Aristolactam, Aristolactam-C N- } \beta \text {-D Glucoside, Aristolactam } \beta \text {-D Glucoside }\end{array}$ & Root & Mix et al., 1982 \\
\hline & Aristolochic acid I & Root & Kupchan and Doskotch, 1962 \\
\hline & $\begin{array}{l}\text { Savinin, Aristolochic acid-I, (+)-ledol, (12s)- 7,12-secoishwaran- 12-ol, Aristolactam N- } \beta \text {-D- } \\
\text { Glucoside, Aristolactam, Aristolactam A-II, Methyl Aristolochate, Aristolochic acid-I, } \\
\text { Aristolochic acid-D, Cepharadione A, Aristolindiquinone, Magnoflorine }\end{array}$ & Root & Che et al., 1984 \\
\hline
\end{tabular}


Borah PJ et al. (2021). Not Sci Biol 13(3):11027

\begin{tabular}{|c|c|c|c|}
\hline & $\begin{array}{l}\text { Ishwarone, Ishwarol, } 5 \beta \mathrm{H}, 7 \beta, 10 \alpha \text {-selina4(14), 11-diene, Aristolochine alkaline, } \\
\text { Isoaristolochic acid, Allatonin, }(12 \mathrm{~s}) \text { - } 7 \text {, } 12 \text {-secoishwaran-12-ol, Aristolactam N- } \beta \text {-D- } \\
\text { Glucoside, } 3 \beta \text {-hydroxy-stigmast-5-en-7-one, } 6 \beta \text {-hydroxy-stigmast-4-en-3-one, } \\
\text { Aristolindiquinone, Aristololide, } 2 \text {-hydroxy-1-methoxy-4 Dibenzo quinolone-4,5-(6H)- } \\
\text { dione, Cepharadione, AristolactamIIIa, Aristolactam glycoside I, Stigmastenones II, } \\
\text { Stigmastenones III, Methyl Aristolochate, } \beta \text {-sitosterol- } \beta \text {-D-glucoside, } \alpha \text {-Pinene, trans- } \\
\text { Pinocarveol, Pinocarvone }\end{array}$ & & Dey et al., 2011 \\
\hline & Astragalin, (-) hinokinin, Aristolochic acid I, Aristolactam I, Aristolochic acid II & Aerial part & Desai et al., 2014 \\
\hline & Ishwarone & & Ganguly et al., 1969 \\
\hline & Ishwarane, Aristolochene & Root & Govindachari et al, 1970 \\
\hline & Stigmast-5-en-3 $\beta$-ol ( $\beta$-sitosterol) & Aerial part & Karan et al,, 2012 \\
\hline & $\begin{array}{l}\alpha \text {-pinene, Camphene, } \beta \text {-pinene, p-cymene, Limonene, trans-pinocarveol, Pinocarvone, } \\
\text { Terpinen-4-ol, Myrtenol, Myrtenal, Carvone, } \alpha \text {-terpinyl acetate, Aromadendrene, (E)- } \beta \text { - } \\
\text { ionone, } \alpha \text {-cadinol }\end{array}$ & Stem & Kanjilal et al., 2009 \\
\hline & Aristolochic acid-D, Aristolochic acid-n methyl ether lactam, Aristololactam $\beta$-D-glucoside & Roots & Kupchan and Meriano, 1968 \\
\hline & $\begin{array}{c}\text { Aristolochic acid I, Aristolochic acid II, Aristolochic acid IV, Aristolochic acid D, } \\
\text { Aristolochic acid IIIa, Aristolochic acid Ia, Cepharadione A, Aristolactam I; N- } \beta \text {-D- } \\
\text { glucopyranoside, Aristolactam AII, Aristolactam III, Aristolactam I, Aristolactam IVa, } \\
\text { Aristolactam AIII, Aristolactam II, Aristolactam II; N- } \beta \text {-D-glucopyranoside, Aristolactam } \\
\text { IIIa; N- } \beta \text {-D-glucopyranoside, Aristolactam Ia; N- } \beta \text {-D-glucopyranoside, Aristoloterpenate I, } \\
\text { Ariskanin B, 9-Methoxyaristolactam II, Norcepharadione A }\end{array}$ & Stems, Leaves & Michl et al., 2013 \\
\hline & $\begin{array}{l}\text { Aristolochic acid-A, Aristolochic acid IVa, Methyl Aristolochate, Aristolactam AII, } \\
\text { Aristolactam I, Aristolactam, Aristolochic acid D, Aristololactam-C N- } \beta \text {-D-glucoside, } \\
\text { Aristololactam N- } \beta \text {-D-glucoside }\end{array}$ & & Mix et al., 1982 \\
\hline & (12S)-7,12-secoishwaran-12-ol, (+)-ledol, Ishwarane & Root & Pakrashi et al., 1980 \\
\hline & d-camphor, Sesquiterpene A, Sesquiterpene B, Ishwarane, Ledol & Root & Rao et al, 1955 \\
\hline & $\begin{array}{l}\text { Methyl ester of 12-nonacosenoic acid, n-heptadecane, ntriacontane, Palmitic acid, } \\
\text { hexacosanoic acid, Stigmast-4-en-3-one, Friedelin, Cycloeucalenol, Rutin, Aristolactone }\end{array}$ & Root & Sati et al., 2011 \\
\hline & (S)-Linalool, $\alpha$-Terpinolene, $\beta$-Caryophyllene, Caryophyllene oxide, Caryophyllene oxide, & & Wu et al., 2004 \\
\hline A. cathcartii & Aristolactam I, Aristolactam AII, Aristolochic acid A, Aristolochic acid BII & Whole herb & Zhang et al., 2016 \\
\hline A. saccata & - & - & - \\
\hline A. platanifolia & - & - & - \\
\hline A. assamica & 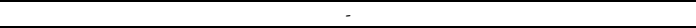 & - & - \\
\hline
\end{tabular}<smiles>O=c1c(O)c(-c2ccc(O)cc2)oc2cc(O)cc(O)c12</smiles>

Kaempferol<smiles>O=C(O)C1Cc2c(ccc3ccc(O)cc23)C2OCOC12</smiles>

Aristolochic acid C

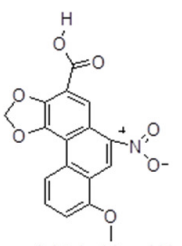

Aristolochic acid I<smiles>COc1cc(O)cc2c1cc([N+](=O)[O-])c1cc(C(=O)O)c3c(c12)OCO3</smiles>

Aristolochic acid D

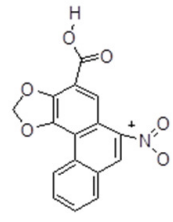

Aristolochic acid II

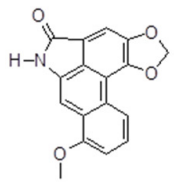

Aristolactam I 
Borah PJ et al. (2021). Not Sci Biol 13(3):11027
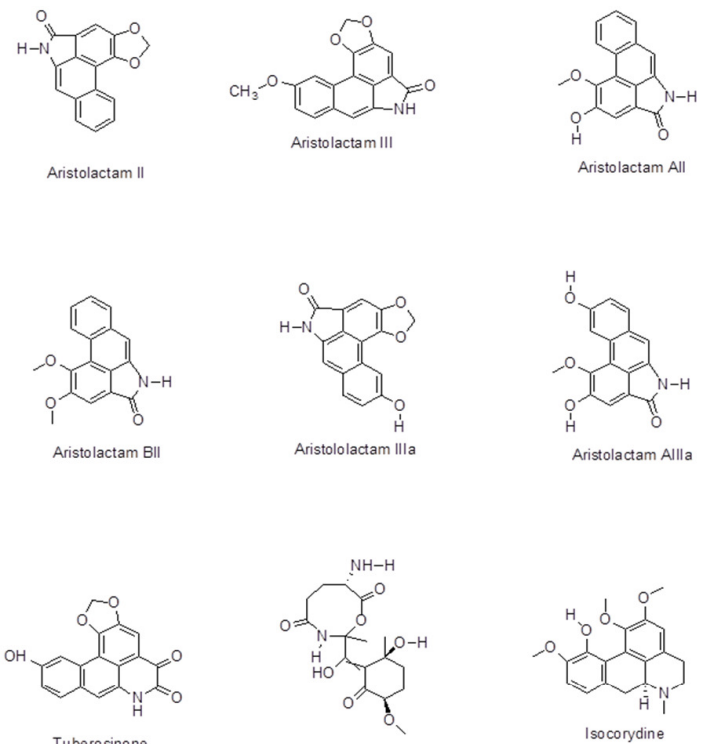

Tuberosinone

Pyriferine A
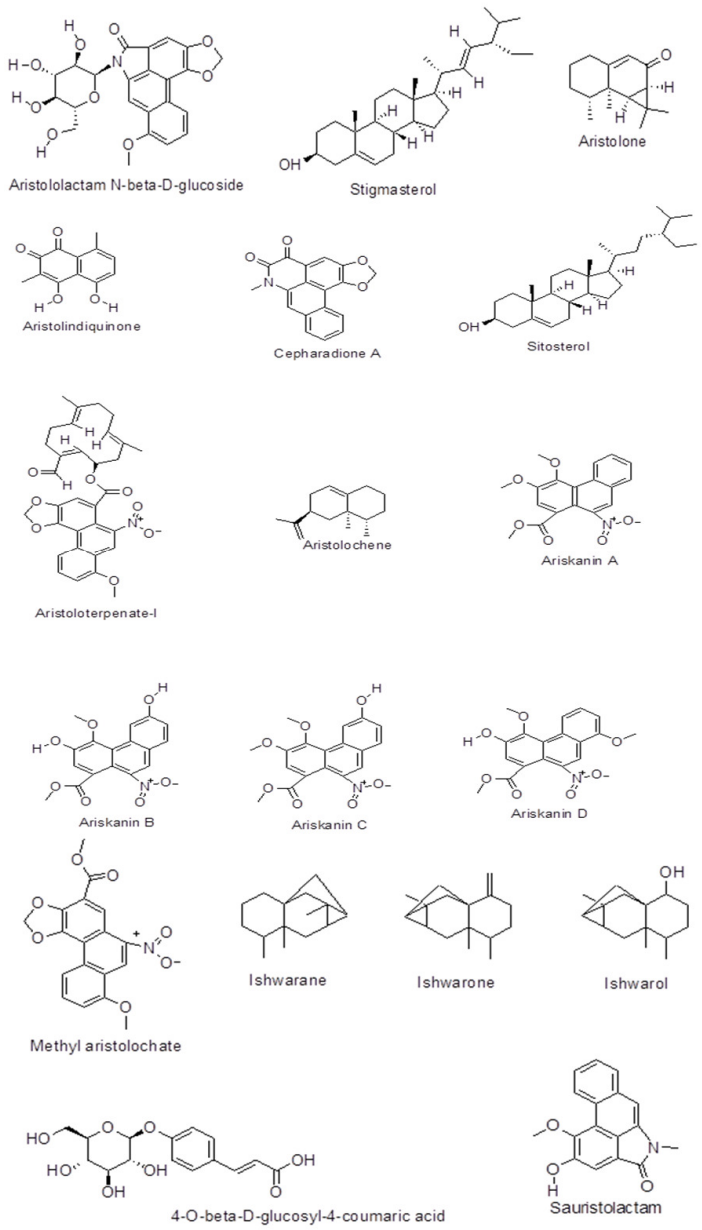

Figure 2. Chemical structures of some important Phyto-constituents of Aristolochia species 


\section{Pharmacological activity of reported Phyto-compounds of Aristolochia}

\section{Antimicrobial activity}

The antibacterial activity of leaves of $A$. acuminata was studied by disc diffusion method against grampositive Staphylococcus lentus and Bacillus cereus, gram-negative Serratia marcescens, Candida albicans, bacteria and fungi Candida dubliniesis and Cryptococcus neoformans. Acetone extract showed the highest inhibition zone against gram-positive organisms than against gram-negative organisms such as Staphylococcus lentus and Bacillus cereus (Hercluis et al., 2018).

Similarly, aerial parts of $A$. indica were also studied by disc diffusion method against Pseudomonas aeruginosa, Basillus subtilis, Staphylococcus aureus, Escherichia coli, Bacillus sphaericus (syn. of Lysinibacillus sphaericus), Salmonella typhimurium. The extracts showed a moderate antibacterial activity (Shafi, 2002). Murugan and Mohan (2012) tested against Staphylococcus aureus, Klebsiella pneumoniae, Bacillus subtilis, Escherichia coli, Salmonella typhi and Pseudomonas aeruginosa and found that petroleum ether, acetone and methanol plant extracts showed good results against all the tested pathogens. Venkatadri et al. (2015) studied the whole plant extracts by agar well diffusion method against multidrug-resistant $\beta$-lactamases producing bacteria and ethanolic extract showed minimum inhibitory concentration values of 50-100 $\mu \mathrm{g} / \mathrm{ml}$ and 100-200 $\mu \mathrm{g} / \mathrm{ml}$. Naik et al. (2015) studied against three Gram-positive (Staphylococcus aureus, Bacillus coagulans, B. subtilis) and three Gram-negative (Escherichia coli, Pseudomonas aeruginosa and Salmonella typhi) bacteria. The leaf extract caused high inhibition of $B$. coagulans followed by $B$. subtilis and the least inhibition caused by leaf extract was recorded against $S$. aureus. In the case of flower extract, $S$. typhi and $B$. coagulans were inhibited to a higher extent when compared to other bacteria. Antifungal activity was studied by poisoned food technique against test fungi namely Bipolaris sorokiniana (from root rot of wheat), Fusarium oxysporum f.sp. zingiberi (from rhizome rot of ginger), Colletotrichum capsici (from anthracnose of chilli) and Curvularia sp. (from mouldy grains of sorghum) and the results revealed that $F$. oxysporum displayed higher susceptibility to leaf and flower extracts followed by Curvularia sp., B. sorokiniana and C. capsici. Umamaheshwari and Murthy (2012) studied against Bacillus subtilis, five different antibiotics namely Ciprofloxacin, Nitrofurantoin, Ofloxacin, Pefloxacin and Sparfloxacin were used as standard, results showed that the root extracts exhibited different degrees of antibacterial activity of which butanol extract of inhibition zone $(2.4 \mathrm{~cm})$ and ether extract $(2.0 \mathrm{~cm})$ showed maximum activity.

\section{Antioxidant activity}

The free radical scavenging activity of methanolic root extracts of $A$. acuminata was tested by Hadem et al. (2016) by DPPH method and, found significant value as compared to standard compound ascorbic acid. At $1000 \mu \mathrm{g} / \mathrm{ml}$ concentration, aqueous stem extract of A. indica showed higher scavenging activity of $66.66 \pm 4.67 \%$ compared to chloroform leaf extract of $48.33 \pm 3.38 \%$ in DPPH method (Subramaniyan et al., 2015). Naik et al. (2015) found the ethyl alcohol extracts of leaves and flowers of A. indica at $100 \mu \mathrm{g} / \mathrm{ml}$ concentration showed $48.68 \%$ and $10.52 \%$ DPPH radical scavenging activity respectively where ascorbic acid was used as standard. The aerial parts of A. indica exhibited IC50 value of $7.325 \mu \mathrm{g} / \mathrm{ml}$ at $25 \mu \mathrm{g} / \mathrm{ml}$ concentration when tested by DPPH radical scavenging method using ascorbic acid as standard and IC 50 value of $8.498 \mu \mathrm{g} / \mathrm{ml}$ at $10 \mu \mathrm{g} / \mathrm{ml}$ concentration when tested by superoxide anion radical scavenging method with curcumin as standard (Karan et al., 2012). Thirugnanasampandan et al. (2008) studied the antioxidant activities of both $A$. acuminata and $A$. indica using three solvents e.g., petroleum ether, chloroform and ethyl acetate extract. Among the extracts, the highest reducing power activity has shown by the ethyl acetate extract of $A$. acuminata (1.28\%) and $A$. indica (1.01\%). In Ammonium thiocyanate assay, petroleum ether $(10 \mathrm{ml})$ extract of $A$. acuminata showed the highest activity of $57.42 \%$ and $A$. indica ethyl acetate extract showed the highest activity of $40.21 \%$ compared to Linoleic acid. 


\section{Anti-inflammatory activity}

Ethyl acetate and ethanol extracts of $A$. acuminata roots at doses 200 and $400 \mathrm{mg} / \mathrm{kg}$ produced a significant reduction in the Carrageenan-induced paw edema on Wistar albino rats. The test samples exhibited an inhibitory effect for both COX and LOX enzymes, in in-vitro MTT colorimetric assay. Among the isolated phytoconstituents from the plant "Kaempferol" was responsible for the highest inhibition of PGE2 and LTB4 at $87.7 \%$ and $91.4 \%$ released from calcium ionophore and LPS IFN $\gamma$-stimulated macrophages than standard drug indomethacin (Battu et al., 2011). Aristolactam I and (-) Hinokinin isolated from $A$. indica also exerted anti-inflammatory effects and inhibited the production of IL- 6 and cytokines TNF- $\alpha$ in LPS-stimulated THP1 cells (Desai et al., 2014). Retardation of inflammation has resulted when combined administration of $A$. indica plant extract and venom Ichthyocrinotoxin administered on Carrageenan induced male albino rats (Das et al., 2010). Ethanolic extract of $A$. indica roots at dose $150 \mathrm{mg} / \mathrm{kg}$ showed a potent anti-inflammatory effect on compound 48/80 induced paw edema in Wistar male albino rats (Mathew et al., 2011).

\section{Anti-cancer activity}

Hepatocellular carcinoma (HCC) in Swiss albino BALB/c mice was induced by carcinogen diethylnitrosamine (DEN) which elevates aspartate transaminases, alanine transaminase, alkaline phosphatase activities. A. acuminata root extract significantly attenuated the increased activities of these marker enzymes (Hadem et al., 2014). It was found the root extracts had lowered the levels of tumour necrosis factor- $\alpha$ (TNF- $\alpha$ ) levels and nuclear factor kappa-B (NF- $\kappa \mathrm{B})$ activation when analysed the serum and nuclear extracts of DEN induced hepatocellular carcinoma in Albino BALB/c mice. Leaves and stem extracts of this plant also showed chemo-preventive potentiality when tested against six human cancer cell lines (Garg et al., 2007). Fractions of A. acuminata root aqueous-methanol extract of $2.5-5 \mathrm{mg} / \mathrm{ml}$ concentration exhibited the highest inhibition with IC $5_{50}$ value of $0.320 \mathrm{mg} / \mathrm{ml}$ and induced the effective apoptotic activity determined by MTT assay in HeLa cells (Hadem et al., 2019).

The chloroform leaves extract of $A$. indica showed an inhibitory effect at $\mathrm{IC}_{50}$ value at $347 \mu \mathrm{g} / \mathrm{ml}$ compared to the standard anti-cancer therapy drug Taxol when evaluated in human breast cancer cell line (MCF-7 Michigan Cancer Foundation-7) by MTT assay (Subramaniyan et al., 2015).

\section{Anti-diabetic activity}

The experimental findings of Karan et al. (2012) confirmed the aerial parts of $A$. indica possess significant anti-diabetic properties. A single intravenous injection of aqueous alloxan monohydrate (150 $\mathrm{mg} / \mathrm{kg}$ ) induced diabetes mellitus in Swiss albino mice and Glibenclamide considered as standard drug resulted that after four hours of the administration of chloroform plant extract showed maximum reduction in serum glucose level at the doses of $(100,250,500,750 \mathrm{mg} / \mathrm{kg}$, p.o) from $226.3 \pm 4.502$ to $198.7 \pm 2.16 \mathrm{mg} / \mathrm{dl}$, $244.2 \pm 3.76$ to $206.5 \pm 1.871 \mathrm{mg} / \mathrm{dl}, 414.2 \pm 3.869$ to $187.2 \pm 2.312$ and $273 \pm 3.742$ to $184.7 \pm 3.141 \mathrm{mg} / \mathrm{dl}$. Methanolic extracts of $A$. indica roots at doses 100,200 and $400 \mathrm{mg} / \mathrm{kg}$ showed anti-hyperglycemic effect on alloxan induced diabetic mellitus in Sprague Dawley rats and compared with the oral hypoglycemic agent glibenclamide $(10 \mathrm{mg} / \mathrm{kg})$. The effect of crude extract on blood glucose levels was measured at various time intervals of $0,1,2,4,6$ and 8 hours. The dose of $400 \mathrm{mg} / \mathrm{kg}$ of the crude extract produced a significant maximum fall of $28.94 \pm 2.8$ on the blood glucose levels of diabetic rats after 6 hours of the treatment compared with disease control group (Goverdhan et al., 2008).

\section{Anti-fertility activity}

The anti-fertility activity was evaluated by determining the anti-implantation and early abortifacient activity of ethanolic extract of $A$. acuminata leaves in Wistar rats of either sex orally at the doses of 100 and 200 $\mathrm{mg} / \mathrm{kg}$ considering $1 \%$ Tween 80 as control drug showed significant (100\%) antifertility activity on $200 \mathrm{mg} / \mathrm{kg}$ in female rats by a significant reduction in the number of corpora lutea and increase in the number of 
resorptions (Balaji et al., 2004). The post-coital administration of $A$. indica ethanolic root extract decreased fertility in both Wistar rats and hamsters (Che et al., 1984).

\section{Anti-venom activity}

Screening of $A$. indica plant extract against snake (Daboia russelli) venom (Meenatchisundaram et al., 2009) and scorpion (Mesobuthus tamulus) venom (Attarde and Apte, 2013) showed potent venom neutralizing capacity. $0.11 \mathrm{mg}$ of plant extracts were able to completely inhibit PLA2 dependent haemolysis of sheep RBC's induced by $D$. russelli venom and $4 \mathrm{mg}$ of plant extracts were able to completely inhibit PLA2 dependent haemolysis of mice RBC's induced by red scorpion venom in dose dependent manner. The plant extract of $A$. indica is effective in neutralization of lethal venom effects of 2LD50 of D. russelli venom and LD99 of $M$. tamulus (red scorpion) venom. Additionally, the pro-coagulant activity showed $1.6 \mathrm{mg}$ and $1 \mathrm{mg}$ of plant extracts were able to completely neutralize coagulant activity in D. russelli venom and red scorpion venom clotted human citrated plasma. The modified plaque assay was used to test the fibrinolytic activity, showed $0.11 \mathrm{mg}$ of plant extract was able to completely inhibit fibrinolytic activity (ED50 of $0.5 \mathrm{mg}$ ) induced by $D$. russelli venom. The popular bioactive compound of this plant such as Aristolochic acid, Sesquiterpenes, Aristololide works in the modification of the actions of proteins and enzymes which are responsible for the anti-scorpion venom property.

\section{Anti-diarrhoeal activity}

The anti-diarrhoeal activity of $A$. indica ethanol and aqueous root extract tested in castor oil-induced diarrhoea male Swiss albino mice resulted the inhibition of $72.38 \%$ and $61.94 \%$ at a higher dose level $400 \mathrm{mg} / \mathrm{kg}$ as compared with diphenoxylate $\mathrm{HCl}$. A delay of the intestinal transit in charcoal meal-induced mice was recorded at the doses of $200 \mathrm{mg} / \mathrm{kg}$ and $400 \mathrm{mg} / \mathrm{kg}$ of plant extract confirmed the significant result in charcoal induced gastrointestinal motility test (Dharmalingama et al., 2014).

\section{Anti-pruritic activity}

Compound 48/80 induced scratched behaviour model was used to evaluate the scratching response of A. indica root. The ethanolic plant extract at the dose of $150 \mathrm{mg} / \mathrm{kg}$ showed significant effect and decreased the scratching incidence (Mathew et al., 2011). The wound healing potency $A$. saccata leaf extract was studied by Bolla et al. (2019). In vitro cell-based scratch assay in L929 cells resulted after 48 hours of treatment with $125 \mu \mathrm{g} / \mathrm{mL}$ of plant extract closed the gap created by the scratch by $93.525 \%$. The extracellular matrix (ECM) factor, collagen type- 1 might be enhanced by the plant extract which initiated the migration of fibroblasts (Bolla et al., 2019).

\section{Anti-feedant activity}

Antifeedant activity studied by Baskar et al. (2011) reported the leaf extract of $A$. acuminata was more toxic than the root extract. Maximum anti-feedant activities of $56.06 \%$ and $49.86 \%$ were recorded on ethyl acetate and hexane leaf extracts of $A$. acuminata at 5.0\% concentration against Spodoptera litura using leaf disc no-choice method while the root ethyl acetate extract expressed minimum activity of $31.71 \%$. At the same concentration, the ethyl acetate leaf extract exhibited the highest larvicidal activity (40.66\%) and pupicidal activity (68.06\%). Significant larval toxicity showed by $A$. indica leaf against Anopheles stephensi. The formulation of Aristolochic acid I at concentrations of $1000 \mathrm{ppm}$ reduced the survival of all larval instars (Murugan et al., 2015; Pradeepa et al., 2015).

\section{Toxicology}

The aristolochic acids found among the species of Aristolochia are famous for nephrotoxicity after the tragic Belgian cohort where the women have taken the weight reducing pills contained Chinese herb, Stephania tetrandra was inadvertently replaced by aristolochic acid-containing $A$. fangchiwere reported to suffering renal 
interstitial fibrosis (Balachandran et al., 2005; Debelle et al., 2008). The nephrotoxic and carcinogenic properties of the compound aristolochic acids have been recognised and can cause permanent kidney injury, renal failure (Han et al., 2019). The toxicological risk on the consumption of drugs made up of $A$. indica depends upon several factors like processing, preparation of drugs and mode of administration (Michl et al., 2013). In the quality control of the herbal recipe Homnawakod, Tripatara et al. (2012) demonstrated that one of its formulations e.g., the dried roots of $A$. acuminata were not causing nephrotoxicity in rats even the daily administration for 21 days. The acute toxicity study revealed no cytotoxic effects of $A$. acuminata leaves and root, $A$. indica aerial parts and roots when tested in both Swiss albino mice and Wistar albino rats (Balaji et al., 2004; Battu et al., 2011; Mathew et al., 2011; Karan et al., 2012). Leaves of $A$. saccata exhibited mild toxicity against L929 fibroblast cell line at minimum percentage resulted in the death of only $2.88 \%$ of cells (Bolla et al., 2019). Michl et al. (2013) also reported the contents of Aristolochic acid is higher in leaves, fruits and young stem than roots and woody stems.

\section{Conservation status of Aristolochia at the local level}

Mostly the roots of the Aristolochia sp. are used for a different form of traditional medicine, which arise a problem, as most plants are uprooted directly from the wild before reaching reproductive maturity. This poses a serious threat and is also elucidated by Kayang (2007). However, effective planning on cultivation and management of Aristolochia on a small scale can help address this issue, as well as introduction in the home gardens can solve this problem. They can also be planted as beautiful ornamental. The attractive flowers add aesthetic value to its present traditional utilities.

\section{Conclusions}

The plants of the genus Aristolochia have always been recognized as plants of high medicinal importance by the people of Northeast India. But in recent years, the genus Aristolochia L. has been recognized globally for possessing remarkable medicinal value and is reportedly used by people throughout the Indian sub-continent against various diseases and illnesses such as snake bites, muscular ailments, lung, liver and gastrointestinal disorders etc. Hence, in this present study, we have comprehensively reviewed the traditional knowledge on six species of Aristolochia found in the northeastern state of Assam along with the various phytoconstituents present in those species. Also, the various properties viz. antimicrobial, antioxidant, anti-inflammatory, anticancer, anti-diabetic, anti-fertility, anti-venom, anti-diarrhoeal, anti-pruritic, antifeedant and toxic activity exhibited by various parts of the plant. In short, this review is designed to provide insight into the necessity of further research of important plant compounds to investigate and develop new drugs. Additionally, more comprehensive reviews regarding the activity of the compounds found in Aristolochia will help in further development of using Aristolochia as an effective drug. Hopefully, these studies will explore the full potential of Aristolochia and optimize its use as a promising herbal medicine, thereby promoting global health.

\section{Authors' Contributions}

Conceptualization: DB; Data Curation: DB, PJB; Formal analysis: DB, RS; Writing original draft: PB; Writing-review and editing: UD, TJD.

All authors read and approved the final manuscript. 
Borah PJ et al. (2021). Not Sci Biol 13(3):11027

\section{Acknowledgements}

The authors are thankful to Mr. Khyanjeet Gogoi and Mr. Goutam Panda for their pictures of $A$. platanifolia and $A$. indica.

\section{Conflict of Interests}

The authors declare that there are no conflicts of interest related to this article.

\section{References}

Achari B, Chakrabarty S, Pakrashi SC (1981). An N-glycoside and steroids from Aristolochia indica. Phytochemistry 20(6):1444-1445. https://doi.org/10.1016/0031-9422(81)80066-0

Attarde S, Apte K (2013). Studies on antivenom activity of Aristolochia indica plant extract against red scorpion venom by in vivo and in vitro methods. International Journal of Pharmacognosy and Phytochemical Research 5(3):168172.

Balachandran P, Wei F, Lin RC, Khan IA, Pasco DS (2005). Structure activity relationships of aristolochic acid analogues: Toxicity in cultured renal epithelial cells. Kidney International 67:1797-1805. https://doi.org/10.1111/j.15231755.2005.00277.x

Balaji S, Raj PP, Thomas J, Kumar KA (2004). Antifertility activity of ethanol extract of Aristolochia tagala leaf. Indian Journal of Pharmaceutical Sciences 66:843.

Basak S, Banerjee A, Manna CK (2016). Role of some ethno medicines used by the Santal tribal people, of the district Bankura, W.B., India, for abortifacient purposes. Journal of Medicinal Plants Studies 4:125-129.

Baskar K, Sasikumar S, Muthu C, Kingsley S, Ignacimuthu S (2011). Bio efficacy of Aristolochia tagala Cham. against Spodoptera litura Fab. (Lepidoptera: Noctuidae). Saudi Journal of Biological Sciences 18(1):23-27. https://doi.org/10.1016/j.sjbs.2010.09.004

Basumatary N, Teron R, Saikia M (2014). Ethnomedicinal practices of the Bodo-Kachari tribe of Karbi Anglong district of Assam. International Journal of Life Sciences Biotechnology and Pharma Research 3(1):161-167.

Battu GR, Parimi R, Chandra Shekar KB (2011). In vivo and in vitro pharmacological activity of Aristolochia tagala (syn: Aristolochia acuminata) root extracts. Pharmaceutical Biology 49(11):1210-1214. https://doi.org/10.3109/13880209.2011.589855

Bhandary MJ, Chandrasekhar KR (2011). Herbal therapy for herpes in the ethno-medicine of Coastal Karnataka. Indian Journal of Traditional Knowledge 10(3):528-532.

Bhat P, Hedge GR, Hedge G, Mulgund GS (2014). Ethnomedicinal plants to cure skin diseases- An account of the traditional GR knowledge in the coastal parts of Central Western Ghats, Karnataka, India. Journal of Ethnopharmacology 151:493-502. https://doi.org/10.1016/j.jep.2013.10.062

Biswas A, Bari MA, Roy M, Bhadra SK (2010). Inherited folk pharmaceutical knowledge of tribal people of Chittagong Hill tracts, Bangladesh. Indian Journal of Traditional Knowledge 9(1):77-89.

Bolla SR, Al-Subaie AM, Al-Jindan RY, Balakrishna JP, Ravi PK, Veeraraghavan VP, Pillai AA, ... Surapaneni KM (2019). In vitro wound healing potency of methanolic leaf extract of Aristolochia saccata is possibly mediated by its stimulatory effect on collagen-1 expression. Heliyon 5(5):e01648. https://doi.org/10.1016/j.heliyon.2019.e01648

Borah D, Tangjang S, Das AP, Upadhyaya A, Mipun P (2020). Assessment of non-timber forest products (NTFPs) in Behali Reserve Forest, Assam, Northeast India. Ethnobotany Research and Applications 19(43):1-15. https://doi.org/10.32859/era.19.43.1-15

Borah D, Taram M, Das AP, Tangjang S, Do TV (2019). Aristolochia assamica (Aristolochiaceae), a new species from the East Himalayas. Annales Botanica Fennici 56:253-257. https://doi.org/10.5735/085.056.0410

Borah PK, Gogoi P, Phukan AC, Mahanta J (2006). Traditional medicine in the treatment of gastrointestinal diseases in upper Assam. Indian Journal of Traditional Knowledge 5(4):510-512.

Bose NMFJ, Aron S, Mehalingam P (2014). An ethnobotanical study of medicinal plants used by Paliyars aboriginal community in Virudhunagar district, Tamil Nadu, India. Indian Journal of Traditional Knowledge 13:613-618. 
Britto JD, Mahesh R (2007). Exploration of Kani tribal botanical knowledge in Agasthyamalai Biosphere Reserve, South India, India. Ethnobotanical Leaflets 11:258-265.

Chakraborty MK, Bhattacharjee A (2006). Some common ethnomedicinal uses for various diseases in Purulia district, West Bengal. Indian Journal of Traditional Knowledge 5(4):554-558.

Che CT, Ahmed MS, Kang SS, Waller DP, Bingel AS, Lankin DC, ... Fong HHS (1984). Studies on Aristolochia III isolation and biological evaluation of constituents of Aristolochia indica roots for fertility-regulating activity. Journal of Natural Products 47(2):331-341.

Chen ZL, Zhu DY (1987). Aristolochia alkadoids. In: Arnold B (Ed). The Alkaloids: Chemistry and Pharmacology. Academic Press pp 3-9.

Choudhary MS, Mishra N, Upadhyay ST, Upadhyay R (2011). Indigenous knowledge of using medicinal plants in treating skin diseases by tribal's in central Narmada valley of Madhya Pradesh (India). Bulletin of Environment, Pharmacology and Life Sciences 1(1):60-63.

Das A, Bondya SL (2015). Indigenous herbal healers of Dumka District: Repositories of ethno-medicines. International Journal for Exchange of Knowledge 2(1):25-33.

Das PK, Mondal AK (2012). A report to the rare and endangered medicinal plants resources in the dry deciduous forest areas of Paschim Medinipur district, West Bengal, India. International Journal of Drug Discovery and Herbal Research 2(2):418-429.

Das R, Kausik A, Pal TK (2010). Anti-inflammatory activity study of antidote Aristolochia indica to the venom of Heteropneustes fossilis in rats. Journal of Chemical and Pharmaceutical Research 2(2):554-562.

Debelle FD, Vanherweghem JL, Nortier JL (2008). Aristolochic acid nephropathy: A worldwide problem. Kidney International 74(2):158-169. https://doi.org/10.1038/ki.2008.129

Desai DC, Jacob J, Almeida A, Kshirsagar R, Manju SL (2014). Isolation, structural elucidation and anti-inflammatory activity of astragalin, (-) hinokinin, aristolactam I and aristolochic acids (I \& II) from Aristolochia indica. Natural Product Research 28(17):1413-1417. https://doi.org/10.1080/14786419.2014.905563

Devendrakumar D, Anbazhagan M (2012). Ethnoveterinary medicinal plants used in Perambalur District, Tamil Nadu. Research in Plant Biology 2:24-30.

Devi Prasad AG, Shyma TB, Raghavendra MP (2013). Plants used by the tribes for the treatment of digestive system disorders in Wayanad district, Kerala. Journal of Applied Pharmaceutical Science 3(08):171-175. https://doi.org/10.7324/JAPS.2013.3830

Dey A, De J (2011). Aristolochia indica: a review. Asian Journal of Plant Sciences 10(2):108-116.

Dey A, De JN (2012). Traditional use of plants against snakebite in Indian Subcontinent: A review of the recent literature. African Journal of Traditional, Complementary and Alternative Medicines 9(1):153-174. https://doi.org/10.4314/ajtcam.v9i1.20

Dey A, Nath DJ (2012). Pharmacology and medicobotany of Aristolochia tagala Cham: A review. Pharma Science Monitor 3(1):110-122.

Dharmalingama SR, Madhappanb R, Ramamurthya S, Chidambarama K, Srikantha MV, Shanmughama S, Senthil Kumar KL (2014). Investigation on antidiarrhoeal activity of Aristolochia indica Linn. root extracts in mice. African Journal of Traditional, Complementary and Alternative Medicines 11(2):292-294. https://doi.org/10.4314/ajtcam.v11i2.11

Do TV, Luu TH, Wanke S, Neinhuis C (2015). Three new species and three new records of Aristolochia subgenus Siphisia from Vietnam including a key to the Asian species. Systematic Botany 40(3):671-691. https://doi.org/10.1600/036364415X689140

Galav P, Jain A, Katewa SS (2013). Traditional veterinary medicine used by livestock owners of Rajasthan, India. Indian Journal of Traditional Knowledge 12(1):47-55.

Ganesan S, Chandhirasekaran M, Selvaraj A (2008). Ethnoveterinary healthcare practices in southern districts of Tamil Nadu. Indian Journal of Traditional Knowledge 7(2):347-354.

Ganguly AK, Gopinath KW, Govindachari TR, Nagarajan K, Pai BR, Parthasarathy PC (1969). Ishwarone, a novel tetracyclic sesquiterpene. Tetrahedron Letters 3:133-136. https://doi.org/10.1016/S0040-4039(01)87491-8

Garg A, Darokar MP, Sundaresan V, Faridi U, Luqman S, Rajkumar S, Khanuja SPS (2007). Anticancer activity of some medicinal plants from high altitude evergreen elements of Indian Western Ghats. Journal of Research and Education in Indian Medicine 13:1-6. 
Goverdhan P, Sandhya Rani M, Thirupathi K, Rani S, Sathesh S, Ravi Kumar B, Mohan GK (2008). Hypoglycemic and antihyperglycemic effect of Aristolochia indica normal and alloxan induced diabetic rats. Pharmacologyonline $1: 20-29$.

Govindachari TR, Mohamed PA, Parthasarathy PC (1970). Ishwarane and Aristolochene, two new sesquiterpene hydrocarbons from Aristolochia indica. Tetrahedron 26(2):615-619. https://doi.org/10.1016/S00404020(01)97854-8

Gritto MJ, Nanadagopalan V, Doss A (2015). Ethnobotanical survey of medicinal plants used by traditional healers in Shobanapuram village of Pachamalai Hill, Tamilnadu. Advances in Applied Science Research 6(3):157-164.

Gupta VK, Singh GD, Singh S, Kaul A (2010). Medicinal plants: phytochemistry, pharmacology and therapeutics, Vol 1. Daya Publishing House, Delhi, India.

Hadem KLH, Sen A (2019). Identification of compounds of Aristolochia tagala and apoptotic activity in HeLa cells. Pharmacognosy Magazine 14(59):571-577.

Hadem KLH, Sharan RN, Kma L (2014). Inhibitory potential of methanolic extracts of Aristolochia tagala and Curcuma caesia on hepatocellular carcinoma induced by diethylnitrosamine in BALB/c mice. Journal of Carcinogenesis 13:7. https://doi.org/10.4103/1477-3163.133520

Hadem KLH, Sharan RN, Kma L (2016). Phytochemicals of Aristolochia tagala and Curcuma caesia exert anticancer effect by tumor necrosis factor- $\alpha$-mediated decrease in nuclear factor kappaB binding activity. Journal of Basic and Clinical Pharmacy 7(1):1-11. https://doi.org/10.4103/0976-0105.170585

Han J, Xian Z, Zhang Y, Liu J, Liang A (2019). Systematic overview of Aristolochic acids: Nephrotoxicity, carcinogenicity, and underlying mechanisms. Frontiers in Pharmacology 10:648. https://doi.org/10.3389/fphar.2019.00648

Hercluis, Kumar DS, Koilpillai YJ (2018). Evaluation of the antimicrobial efficacy of Aristolochia tagala leaf extract against selected human pathogenic bacteria and fungi. International Journal of Innovative Research in Technology 5(2):344-347.

Hiremath VT, Taranath TC (2010). Traditional phytotherapy for snake bites by tribes of Chitradurga District, Karnataka, India. Ethnobotanical Leaflets 14:120-125.

Hwang SM, Kelly LM, Gilbert MG (2003). Aristolochiaceae. In: Wu Z, Peter HR, Hong D (Eds). Flora of China. Science Press, Beijing and Missouri Botanical Garden Press, St. Louis pp 246-269.

Ignacimuthu S, Ayyanar M (2005). Medicinal plants used by the tribals of Tirunelveli hills, Tamil Nadu to treat poisinous bites and skin diseases. Indian Journal of Traditional Knowledge 4(3):229-236.

Ioset J, Raoelison GI, Hostettmann K (2002). An LC/DAD-UV/MS method for the rapid detection of aristolochic acid in plant preparations. Planta Medica 68:856-858. https://doi.org/10.1055/s-2002-34413

Jain A, Katewa SS, Galav P, Nag A (2008). Some therapeutic uses of biodiversity among the tribals of Rajasthan. Indian Journal of Traditional Knowledge 7(2):256-262.

Jeeva S, Kiruba S, Mishra BP, Venugopal N, Dhas SSM, Regini GS, ... Laloo R (2006). Weeds of Kanyakamuri district and their value in real life. Indian Journal of Traditional Knowledge 5(4):501-509.

Jeyaprakash K, Ayyanar M, Geetha KN, Sekar T (2011). Traditional uses of medicinal plants among the tribal people in Theni District (Western Ghats), Southern India. Asian Pacific Journal of Tropical Biomedicine S20-S25. https://doi.org/10.1016/S2221-1691(11)60115-9

Jirovetz L, Buchbauer G, Puschmann C, Fleischhacker W, Shafi PM, Rosamma MK (2000). Analysis of the essential oil of the aerial parts of the medicinal plant Aristolochia indica Linn. (Aristolochiaceae) from South India. Scientia Pharmaceutica 68:309-316.

Johnsy G, Sargunam SD, Kaviyarasan V (2012). Indigenous knowledge of medicinal plants used for the treatment of skin diseases by the Kaani Tribe of Kanyakumari District. International Journal of Pharmacy and Pharmaceutical Sciences 4(1):309-313.

Kamble RB, Somkuwar S, Sharma S, Kamble N, Chaturvedi A (2016). Documentation of aboriginal traditional knowledge and use pattern of folk biomedicines of Deolapar Forest Range, Ramtek. International Journal of Life Sciences A6:153-156.

Kanjilal PB, Kotoky R, Couladis M (2009). Chemical composition of the stem oil of Aristolochia indica L. Journal of Essential Oil Research 21(1):24-25. https://doi.org/10.1080/10412905.2009.9700098

Kanneboyena O, Suthari S, Vatsavaya SR (2015). Ethnomedicinal knowledge of inhabitants from Gundlabrahmeswaram Wildlife Sanctuary (Eastern Ghats), Andhra Pradesh, India. American Journal of Ethnomedicine 2(6):333-346. 
Karan SK, Mishra SK, Pal D, Mondal A (2012). Isolation of $\beta$-sitosterol and evaluation of antidiabetic activity of Aristolochia indica in alloxan-induced diabetic mice with a reference to in-vitro antioxidant activity. Journal of Medicinal Plants Research 6(7):1219-1223. https://doi.org/10.5897/JMPR11.973

Kayang H (2007). Conservation of medicinal plants diversity of Meghalaya in India. In: Pramod T, Yash PA, Suman A (Eds). Biodiversity and its Significance. IK International Publishing House Pvt. Ltd., New Delhi, India pp 233253.

Khan MA (2016). Introduction and Importance of Medicinal Plants and Herbs. Unani. Zahid, India.

Kingston C, Nisha BS, Kiruba S, Jeeva S (2007). Ethnomedicinal plants used by indigenous community in a traditional healthcare system. Ethnobotanical Leaflets 11:32-37.

Kiruba S, Jeeva S, Dhas SSM (2006). Enumeration of ethnoveterinary plants of Cape Comorin, Tamil Nadu. Indian Journal of Traditional Knowledge 5:576-578.

Kumar N, Choyal R, Sharma A (2014). Traditional uses of some plants of Hamirpur district as a blood purifier. International Journal of Theoretical and Applied Sciences 6(2):106-112.

Kumar SJU, Chaitanya KMJ, Semotiuk AJ, Krishna V (2019). Indigenous knowledge of medicinal plants used by ethnic communities of South India. Ethnobotany Research and Applications 18(4):1-112. https://ethnobotanyjournal.org/index.php/era/article/view/1291/801

Kuo PC, Li YC, Wu TS (2012). Chemical constituents and pharmacology of the Aristolochia species. Journal of Traditional and Complementary Medicine 2(4):249-266. https://doi.org/10.1016/s2225-4110(16)30111-0

Kupchan SM, Doskotch RW (1962). Tumor inhibitors I aristolochic acid, the active principle of Aristolochia indica. Journal of Medicinal Chemistry 5:657-659. https://doi.org/10.1021/jm01238a029

Kupchan SM, Meriano JJ (1968). The isolation and structural elucidation of novel derivatives of Aristolochic acid from Aristolochia indica. Journal of Organic Chemistry 33(10):3735-3738.

Liu R, Zhang HC (2020). Chemical constituents from Aristolochia tagala and their chemotaxonomic significance. Biochemical Systematics and Ecology 90:104037. https://doi.org/10.1016/j.bse.2020.104037

Marandi RR, Britto SJ (2014). Ethnomedicinal plants used by the Oraon tribals of Latehar district of Jharkhand, India. Asian Journal of Pharmaceutical Research 4(3):126-133.

Mathew JE, Kaitheri SK, Vachala SD, Jose M (2011). Anti-inflammatory, antipruritic and mast cell stabilizing activity of Aristolochia indica. Iranian Journal of Basic Medical Sciences 14(5):422-427.

Meenatchisundaram S, Parameswari G, Michael A (2009). Studies on antivenom activity of Andrographis paniculata and Aristolochia indica plant extracts against Daboia russelli venom by in vivo and in vitro methods. Indian Journal of Science and Technology 2(4):76-79.

Michl J, Jennings HM, Kite GC, Ingrouille MJ, Simmonds MSJ, Heinrich M (2013). Is aristolochic acid nephropathy a widespread problem in developing countries? A case study of Aristolochia indica L. in Bangladesh using an ethnobotanical-phytochemical approach. Journal of Ethnopharmacology 149(1):235-244. https://doi.org/10.1016/j.jep.2013.06.028

Mix DB, Guinaudeau H, Shamma M (1982). The aristolochic acids and aristolactams. Journal of Natural Products 45(6):657-666. https://doi.org/10.1021/np50024a001

Murthy EN (2012). Ethno medicinal plants used by Gonds of Adilabad district, Andhra Pradesh, India. International Journal of Pharmacy and Life Sciences 3(10):2034-2043.

Murugan K, Labeeba MA, Panneerselvam C, Dinesh D, Suresh U, Subramaniam J, ... Benelli G (2015). Aristolochia indica green-synthesized silver nanoparticles: a sustainable control tool against the malaria vector Anopheles stephensi. Research in Veterinary Science 102:127-135. https://doi.org/10.1016/j.rvsc.2015.08.001

Murugan M, Mohan VR (2012). Efficacy of different solvent extracts of Vitex trifolia L. and Aristolochia indica L. for potential antibacterial activity. Science Research Reporter 2(1):110-114.

Naik AS, Siddiqua S, Shrunga MN, Sunitha KL, Prashith KTR, Raghavendra HL (2015). Antimicrobial and radical scavenging efficacy of leaf and flower of Aristolochia indica Linn. Science, Technology and Arts Research Journal 4(1):103-108. https://doi.org/10.4314/star.v4i1.17

Nath KK, Deka P, Borkataki S, Borthakur SK (2008). Traditional remedies of respiratory disorders from Assam, India. Pleione 2(2):211-216.

Naturu S, Pulicherla Y, Mattigunta L, Devi VRC (2013). Traditional phytotherapy treatment for snake bite and scorpion sting by ethnic groups of Kadapa district, Andhra Pradesh, India. International Journal of Pharmaceutical Sciences Review and Research 20(1):64-70. 
Nithyadevi J, Sivakumar R (2014). Documentation of traditional knowledge of herbal plant in Kalvarayan Hills, Vallupuram District, Tamil Nadu. International Letters of Natural Sciences 7:21-28. https://doi.org/10.18052/www.scipress.com/ILNS.12.21

Nizar MK, Gopakumar S, Kumar V, Ajeesh R (2015). Indigenous Ethnomedicines and victuals of Malayans: An indigenous population of Peechi-Vazhani Wildlife Sanctuary, Western Ghats, India. Indian Journal of Ecology 42(1):9-15.

Ogunmefun OT (2018). Phytochemicals - god's endowment of curative power in plants. Phytochemicals-source of antioxidants and role in disease prevention. IntechOpen.

Oladeji $\mathrm{O}$ (2016). The characteristics and roles of medicinal plants: some important medicinal plants in Nigeria. Natural Products: An Indian Journal 12(3):102.

Pakrashi SC, Dastidar PPG, Chakrabarty S, Achari B (1980). (12S)-7,12-Secoishwaran-12-01, a new type of sesquiterpene from Aristolochia indica Linn. Journal of Organic Chemistry 45:4765-4767. https://doi.org/10.1021/jo01311a043

Panda T, Padhy RN (2008). Ethnomedicinal plants used by tribes of Kalahandi district, Orissa. Indian Journal of Traditional Knowledge 7(2):242-249.

Partha P, Hossain ABME (2007). Ethnobotanical investigation into the Mandi ethnic community in Bangladesh. Bangladesh Journal of Plant Taxonomy 14(2):129-145. https://doi.org/10.3329/bjpt.v14i2.532

Paul S, Devi N, Sarma GC (2011). Medicinal plants of Subankhata Reserve Forest under Dhansiri forest division, Manas Biosphere Reserve in Assam, India. Pleione 5(2):286-291.

Paul S, Devi N, Sarma GC (2011). Medicinal plants of Ultapani forest range under Holtugaon Division, Manas Biosphere Reserve (Assam). International of Journal of Applied Biology and Pharmaceutical Technology 2(4):257-263.

Poornima G, Manasa M, Rudrappa D, Kekuda PTR (2012). Medicinal plants used by herbal healers in Narasipura and Manchale villages of Sagara Taluk, Karnataka, India. Science, Technology and Arts Research Journal 1(2):12-17.

Pradeepa V, Narayanan SS, Kirubakaran SA, Thanigaivel A, Nathan SS (2015). Toxicity of aristolochic acids isolated from Aristolochia indica Linn (Aristolochiaceae) against the malarial vector Anopheles stephensi Liston (Diptera: Culicidae). Experimental Parasitology 153:8-16. https://doi.org/10.1016/j.exppara.2015.01.017

Prakasha HM, Krishnappa M, Krishnamurthy YL, Poornima SV (2010). Folk medicine of NR Pura taluk in Chikmagalur district of Karnataka. Indian Journal of Traditional Knowledge 9(1):55-60.

Prashantkumar P, Vidyasagar GM (2006). Documentation of traditional knowledge on medicinal plants of Bidar district, Karnataka. Indian Journal of Traditional Knowledge 5(3):295-299.

Purkayastha J, Dutta M, Nath SC (2007). Ethnomedicinal plants from Dibru-Saikhowa biosphere reserve, Assam. Indian Journal of Traditional Knowledge 6(3):477-480.

Ragupathy S, Newmaster SG (2009). Valorizing the 'Irulas' traditional knowledge of medicinal plants in the Kodiakkarai Reserve Forest, India. Journal of Ethnobiology and Ethnomedicine 5(10). https://doi.org/10.1186/1746-4269-5-10

Rahman AM, Uddin SB, Wilcock CC (2007). Medicinal plants used by the Chakma tribes in Hill Tracts district of Bangladesh. Indian Journal of Traditional Knowledge 6(3):508-517.

Rahmatullah M, Khatun Z, Barua D, Alam M, Jahan S, Rownak Jahan R (2013). Medicinal plants used by traditional practitioners of the Kole and Rai Tribes of Bangladesh. The Journal of Alternative and Complementary Medicine 19(6):483-491. https://doi.org/10.1089/acm.2012.0227

Rajakumar N, Shivanna MB (2010). Traditional herbal medicinal knowledge in Sagar Taluk of Shimoga District, Karnataka, India. Indian Journal of Traditional Knowledge 1(1):102-108.

Rajashekharan S, Pushpangadan P, Ratheesh Kumar PK, Jawahar CR, Nair CPR, Sarada Amma L (1989). Ethno-medicobotanical studies of CheriyaArayan-and ValiyaArayan- (Aristolochia indica, Linn; Aristolochiatagala, Cham). Ancient Science of Life 9(2):99-106.

Rao AS, Muthana MS (1955). Preliminary studies on the essential oil from Aristolochia indica. Journal of Indian Institute of Science 37.

Rao RR (2019). Medicinal plants of India: diversity, conservation and bioprospection-concerns and strategies for 21 st century. TTPP 1.

Rao VLN, Busi BR, Rao CS, Bharati K, Venkiah M (2010). Ethnomedical study among Savaras of Srikakulam district, Andhra Pradesh. Indian Journal of Traditional Knowledge 9(1):166-168.

Ratnam VK, Raju VRR (2005). Folk medicine used for common women ailments by Adivasis in the Eastern Ghats of Andhra Pradesh. Indian Journal of Traditional Knowledge 4(3):267-270. 
Reang I, Goswami S, Pala NA, Kumar M, Bussmann RW (2016). Ethnoveterinary applications of medicinal plants by traditional herbal healers in Reang Tribeo South District Tripura, India. Medicinal and Aromatic Plants 5:1-4. https://doi.org/10.4172/2167-0412.1000234

Reddy CS, Reddy KN, Murthy EN, Raju VS (2009). Traditional medicinal plants in Seshachalam hills, Andhra Pradesh, India. Journal of Medicinal Plants Research 3(5):408-412.

Reddy SR, Reddy AM, Babu MVS (2015). Traditional medicinal plants of Lankamalleswara Wildlife Sanctuary, Kadapa District, Andhra Pradesh, India. American Journal of Ethnomedicine 2(6):379-391.

Rout SD, Panda SK (2010). Ethnomedicinal plant resources of Mayurbhanj district, Orissa. Indian Journal of Traditional Knowledge 9(1):68-72.

Sambandan K, Dhatchanamoorthy N (2012). Studies on the phytodiversity of a sacred grove and its traditional uses in Karaikal District, U.T. Puducherry. Journal of Phytology 4(2):16-21.

Saradha M, Samydurai P, Divya Bharati G (2017). Documentation of aboriginal traditional knowledge and inherent indigenous therapeutic plants of Coimbatore district, Tamil Nadu, India. Kongunadu Research Journal 4(1):114120.

Sarmah R, Saikia A (2014). Non-timber forest products: diversity and used pattern at Majuli the Brahmaputra River Island of Assam, India. Journal of Botanical Sciences 3(3):41-43.

Sarmah R, Saikia A (2016). Folklore medicine practiced by traditional healers of Fringe villages of Gibbon Wildlife Sanctuary, Assam, India. Acta Biomed Scientia 3(4):227-233.

Sati H, Sati B, Saklani S, Bhatt PC, Mishra AP (2011). Phytochemical and pharmacological potential of Aristolochia indica: A review. Research Journal Pharmaceutical, Biological and Chemical Sciences 2(4):647-654.

Saxena M, Saxena J, Nema R, Singh D, Gupta A (2013). Phytochemistry of medicinal plants. Journal of Pharmacognosy and Phytochemistry 1(6):168-182.

Sen B (2008). Knowledge of wild plants for human and veterinary use in West Bengal; sustainable forest management and poverty alleviation: roles of traditional forest-related knowledge. Vol. 21, IUFRO World Series, Vienna.

Senthilkumar M, Gurumoorthi P, Janardhanan K (2006). Some medicinal plants used by Irular, the tribal people of Marudhamalai hills, Coimbatore, Tamil Nadu. Natural Product Radiance 5(5):383-388.

Shafi PM, Rosamma MK, Jamil K, Reddy PS (2002). Antibacterial activity of the essential oil from Aristolochia indica. Fitoterapia 73(5):439-441. https://doi.org/10.1016/S0367-326X(02)00130-2

Shivakumar HM, Parashurama TR (2014). Phyto-ethno-medicinal knowledge of folklore people in Kappathgudda region of Gadaga District, Karnataka, South India. International Journal of Science and Research 3(11):3081-3091.

Shivanna MB, Rajakumar N (2011). Traditional medico-botanical knowledge of local communities in Hosanagara Taluk of Shimoga District in Karnataka, India. Journal of Herbs, Spices and Medicinal Plants 17:291-317. https://doi.org/10.1080/10496475.2011.602617

Shukla AN, Srivastava S, Rawat AKS (2010). An ethnobotanical study of medicinal plants of Rewa district, Madhya Pradesh. Indian Journal of Traditional Knowledge 9(1):191-202.

Silambarasan R, Sureshkumar J, Krupa J, Amalraj S, Ayyanar M (2017). Traditional herbal medicines practiced by the ethnic people in Sathyamangalam forests of Western Ghats, India. European Journal of Integrative Medicine 16:61-72. https://doi.org/10.1016/j.eujim.2017.10.010

Sivaperumal R, Ramya S, Ravi AV, Rajasekaran C, Jayakumararaj R (2009). Herbal remedies practiced by Malayali's to treat skin diseases. Environment and We - An International Journal of Science and Technology 4:35-44.

Sivasankari B, Anandharaj M, Gunasekaran P (2014). An ethnobotanical study of indigenous knowledge on medicinal plants used by the village peoples of Thoppampatti, Dindigul district, Tamilnadu, India. Journal of Ethnopharmacology 153:408-423. https://doi.org/10.1016/j.jep.2014.02.040

Subramaniyan V, Saravanan R, Baskaran D, Ramalalingam S (2015). In vitro free radical scavenging and anticancer potential of Aristolochia indica L. against MCF-7 cell line. International Journal of Pharmacy and Pharmaceutical Sciences 7(6):392-396.

Sudeesh S (2012). Ethnomedicinal plants used by Malayaraya tribes of Vannapuram village in Idukki, Kerala, India. Indian Journal of Scientific Research and Technology 1(1):7-11.

Sulochana AK, Raveendran D, Krishnamma AP, Oommen V (2014). Ethnomedicinal plants used for snake envenomation by folk traditional practitioners from Kallar forest region of South Western Ghats, Kerala, India. Journal of Intercultural Ethnopharmacology 4(1):47-51. https://doi.org/10.5455/jice.20141010122750

Swarnalatha AM, Buraka KS, Kalavatamma PC (2017). Indigenous healthcare practices of rural women for digestive disorders in Andhra Pradesh. Journal of Pharmacognosy and Phytochemistry SP1:882-886. 
Syiem D, Kharbuli B, Myrboh B, Buam DRM (2006). Medicinal plants and herbal medicine: A case study in Meghalaya. Biodiversity in Northeast India. NEHU publications, Shillong, India.

Taid TC, Rajkhowa RC, Kalita JC (2014). A study on the medicinal plants used by the local traditional healers of Dhemaji district, Assam, India for curing reproductive health related disorders. Advances in Applied Science Research 5(1):296-301.

Teron R (2019). Cross-Cultural ethnobotanical exploration of diversity and utilization of medicinal plants in KarbiAnglong district, Assam, Northeast India. NeBIO 10:35-46.

Teron R, Borthakur SK (2013). Folklore claims of some medicinal plants as antidote against poisons among the Karbis of Assam, India. Pleione 7(2):346-356.

Thirugnanasampandan R, Mahendran G, Narmatha Bai V (2008). Antioxidant properties of some medicinal Aristolochiaceae species. African Journal of Biotechnology 7(4):357-361. https://doi.org/10.5897/AJB07.476

Tiwari DK, Yadav A (2017). Ethnobotanical investigation of some medicinal plants availed by Gond Tribe of Naoradehi Wild Life Sanctuary, Madhya Pradesh. Anthropologist 5(3):201-202. https://doi.org/10.1080/09720073.2003.11890805

Tripatara P, Onlamul W, Booranasubkajorn S, Wattanarangsan J, Huabprasert S, Lumlerdkij N, Akarasereenont P, Laohapand T (2012). The safety of Homnawakod herbal formula containing Aristolochiatagala Cham. in Wistar rats. BMC Complementary and Alternative Medicine 12(1):170. https://doi.org/10.1186/1472-6882-12-170

Tripathi M, Sikarwar RLS (2013). Some traditional herbal formulations of Chitrakoot region, Madhya Pradesh, India. Indian Journal of Traditional Knowledge 12(2):315-320.

Tynsong H, Tiwari BK, Lynser MB (2011). Medicinal plants of Meghalaya, India. Newsletter of MAPPA/ICIMOD, NMPB and MPCN. NEHU, Shillong, India pp 7-10.

Umamaheshwari S, Murthy SM (2012). Antibacterial activity of root of Aristolochia indica on Bacillus subtilis. RGUHS Journal of Pharmaceutical Sciences 2(2):82-85.

Usha S, Rajasekaran C, Siva R (2015). Ethnoveterinary medicine of the Shervaroy Hills of Eastern Ghats, India as alternative medicine for animals. Journal of Traditional and Complementary Medicine 6(1):118-125. https://doi.org/10.1016/j.jtcme.2014.11.013

Venkatadri B, Arunagirinathan N, Rameshkumar MR, Ramesh L, Dhanasezhian A, Agastian P (2015). In vitro antibacterial activity of aqueous and ethanol extracts of Aristolochia indica and Toddalia asiatica against multidrug-resistant bacteria. Indian Journal of Pharmaceutical Sciences 77:788-791. https://doi.org/10.4103/0250-474X.174991

Vijayan A, Lizu VB, John RJV, Parthipan P, Renuka C (2007). Traditional remedies of Kani tribes of Kottoor reserve forest, Agasthyavanam, Thiruvananthapuram, Kerala. Indian Journal of Traditional Knowledge 6(4):589-594.

Wu TS, Damu AG, Su CR, Kuo PC (2004). Terpenoids of Aristolochia and their biological activities. Natural Product Reports 21:594-624. https://doi.org/10.1039/b401950d

Yadav RK, Prakash A (2014). Aromatic medicinal plant resources in Uttar Pradesh, India. Medicinal and Aromatic Plants 3(3):160. https://doi.org/10.4172/2167-0412.1000160

Yesodharan K, Sujana KA (2007). Ethnomedicinal knowledge among Malamalasar tribe of Parambikulam wildlife sanctuary, Kerala. Indian Journal of Traditional Knowledge 6(3):481-485.

Zhang HC, Liu R, An ZP, Li H, Zhang R, Zhou F (2016). Aristolactam-type alkaloids and aristolochic acids from Aristolochia moupinensis and Aristolochia cathcartii. Biochemical Systematics and Ecology 65:198-201.

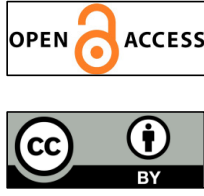

The journal offers free, immediate, and unrestricted access to peer-reviewed research and scholarly work. Users are allowed to read, download, copy, distribute, print, search, or link to the full texts of the articles, or use them for any other lawful purpose, without asking prior permission from the publisher or the author.

License - Articles published in Notulae Scientia Biologicae are Open-Access, distributed under the terms and conditions of the Creative Commons Attribution (CC BY 4.0) License.

(c) Articles by the authors; SHST, Cluj-Napoca, Romania. The journal allows the author(s) to hold the copyright/to retain publishing rights without restriction. 